\title{
Physiological Response to Chilling Temperatures of Intermittently Warmed Cucumber Fruit
}

\author{
Roberto M. Cabrera and Mikal E. Saltveit, Jr. \\ Department of Vegetable Crops, University of California, Davis, CA 95616
}

Additional index words. ethylene, respiration, ion leakage, EFE, ACC

\begin{abstract}
Symptoms of chilling injury were reduced by intermittently warming cucumber fruit (Cucumis sativus L. cv. Poinsett 76) from 2.5 to $12.5 \mathrm{C}$ for $18 \mathrm{hr}$ every 3 days. Fruit continuously held at $2.5 \mathrm{C}$ for 13 days developed severe pitting and decay after 6 days at $20 \mathrm{C}$, while fruit continuously held at $12.5 \mathrm{C}$ or intermittently warmed showed no pitting or decay during subsequent holding at $20 \mathrm{C}$. The increased rate of $\mathrm{C}_{2} \mathrm{H}_{4}$ production during the first warming period, from $12 \mathrm{nl} \cdot(\mathrm{kg} \cdot \mathrm{hr})^{-1}$ at $2.5 \mathrm{C}$ to $201 \mathrm{nl} \cdot(\mathrm{kg} \cdot \mathrm{hr})^{-1}$ at $12.5 \mathrm{C}$, was significantly greater than that during the second or third warming periods, i.e., 53 to 98 and 53 to $55 \mathrm{nl} \mathrm{C}_{2} \mathrm{H}_{4} /(\mathrm{kg} \cdot \mathrm{hr})$, respectively. Respiration increased 3fold during the initial warming period, but only 2 -fold during subsequent warming periods. Leakage of cellular ions from excised disks of mesocarp tissue was around $6 \%$ and $10 \%$ of the total ion content of the tissue for control and intermittently warmed fruit, respectively, but increased to $17 \%$ for fruit that were continuously held at $2.5 \mathrm{C}$ for 10 days. After $320 \mathrm{hr}$ (three cycles) of chilling and warming, chilled fruit showed significantIy lower ethylene-forming enzyme activity than the control or intermittently warmed fruit. Fruit held at $12.5 \mathrm{C}$ contained 0.09 to $0.34 \mathrm{nmol} \cdot \mathrm{g}^{-1}$ of ACC. ACC levels were $6.23 \mathrm{nmol} \cdot \mathrm{g}^{-1}$ in fruit exposed to $2.5 \mathrm{C}$ for $320 \mathrm{hr}$. In contrast, intermittently warmed fruit only showed $30 \%$ and $27 \%$ increases in ACC content during the first and second warming periods, respectively. Periodic warming appears to allow chilled fruit to acclimate to subsequent periods of chilling. Chemical names used: 1-aminocyclopropane-1-carboxylic acid (ACC).
\end{abstract}

Although the storage life of freshly harvested fruits and vegetables is usually prolonged at temperatures near $0 \mathrm{C}$, many horticultural crops of tropical and subtropical origin are chillingsensitive and are injured if held at nonfreezing temperatures below 12C (Lyons, 1973; Saltveit and Morris, 1989). Cucumbers are chilling-sensitive and are injured if held at temperatures $<10 \mathrm{C}$ for more than 3 days (Eaks and Morris, 1956). Chillingsensitive crops can develop symptoms of chilling injury either during storage at chilling temperatures, or subsequently during marketing at nonchilling temperatures. Injury symptoms include the formation of sunken, dark-colored watery areas (pits) and increased susceptibility to decay and fungal growth (Ryan and Lipton, 1979).

Eaks and Morris (1956) reported increased respiration and disease susceptibility and rapid senescence of cucumber fruit held at 0 or 5C. Earlier findings of Mack and Janer (1942) revealed a similar increase in $\mathrm{CO}_{2}$ production of cucumber during storage at 2 to 3C. Wang and Adams $(1980,1981)$ observed an increase in $\mathrm{C}_{2} \mathrm{H}_{4}$ production when cucumbers that had been chilled for 4 days at $2.5 \mathrm{C}$ were transferred to $25 \mathrm{C}$. However, they did not observe an increase in respiration or $\mathrm{C}_{2} \mathrm{H}_{4}$ production during the chilling period (Wang and Adams, 1980). Increased production of $\mathrm{C}_{2} \mathrm{H}_{4}$ by chilled cucumbers could reduce quality, since it has been shown that exposure to $\mu \mathrm{C}_{2} \mathrm{H}_{2} /$ liter $(\mathrm{ppm})$ air mixtures accelerates the senescence of cucumber fruit (Saltveit and McFeeters, 1980).

Postharvest temperature treatments that reduce symptoms of chilling injury include conditioning at near-chilling temperatures and intermittent warming during chilling (Morris, 1982; Wang, 1982). Chilling injury has been reduced in fruits of bell pepper (Wang and Baker, 1979), grapefruit (Davis and Hoffmann, 1973), and tomato (Saltveit and Cabrera, 1987), and tomato seedlings

Received for publication 18 May 1989. Appreciation is expressed to Peto Seed Research Center, Woodland, Calif., for providing cucumber fruits. We also express our appreciation to Fabio Mencarelli, a visiting scientist from the Istituto di Technologies University Della Tuscia, Viterbo, Italy, for his assistance in this research. The cost of publishing this paper was defrayed in part by the payment of page charges. Under postal regulations, this paper therefore must be hereby marked advertisement solely to indicate this fact. and ornamental (Morris, 1982; Wheaton and Morris, 1967) by conditioning them at cool, nonchilling temperatures before chilling. Intermittent warming has been reported to reduce chilling injury in bell peppers (Wang and Baker, 1979), citrus (Davis and Hofmann, 1973; Eaks, 1965), cucumbers (Wang and Baker, 1979; Hirose, 1985), okra (Ilker, 1976), potatoes (Hruschka et al., 1968), and peaches and nectarines (Anderson, 1982; Wang and Anderson, 1982).

Ethylene synthesis progresses from the amino acid methionine to S-adenosylmethionine to ACC to $\mathrm{C}_{2} \mathrm{H}_{4}$ (Yang, 1980). ACC is converted to $\mathrm{C}_{2} \mathrm{H}_{4}$ by the ethylene-forming enzyme (EFE). The rate at which $\mathrm{C}_{2} \mathrm{H}_{4}$. is produced in most tissues is governed by the rate at which ACC is synthesized, although under some conditions the EFE activity may be the rate-controlling step.

The objective of our present study was to determine the effect of intermittent warming during chilling on the respiration and $\mathrm{C}_{2} \mathrm{H}_{4}$ metabolism of cucumber fruits, and to evaluate the effect of intermittent warming on alleviating symptoms of chilling injury.

\section{Materials and Methods}

Plant materials. 'Poinsett 76' cucumber fruits were handharvested from the Peto Seed Research Center in Woodland, Calif. Nine uniform fruit, blocked for size and shape among treatments and free from injury, were used in each treatment. Fruit were placed in shallow plastic trays that were covered loosely with a plastic film to minimize water loss.

Temperature management. The time to warm and/or cool individual cucumber fruit when transferred between the two experimental temperatures of 2.5 and $12.5 \mathrm{C}$ was determined by periodically recording the temperature shown by a thermometer inserted in the seed cavity of each of nine fruit used only for this purpose. The half-time for either warming or cooling was about an hour.

There were three temperature treatments: 1) control fruit were continuously held at $12.5 \mathrm{C} ; 2$ ) chilled fruit were continuously held at $2.5 \mathrm{C}$; and 3 ) intermittently warmed fruit were held at $2.5 \mathrm{C}$ for 3 or 4 days and warmed at $12.5 \mathrm{C}$ for $18 \mathrm{hr}$ before 
transfer back to the chilling temperature. Intermittently warmed fruit were subjected to from one to three temperature cycles. All fruit were subsequently evaluated at 20C. Each experiment was repeated with similar results.

Pitting and decay. The incidence of pitting and decay was determined subjectively by an 8-point Hedonic scale, where $0=$ no pitting or decay $(0 \%$ of the surface area was pitted or decayed), $2=$ slight $(1 \%$ to $5 \%), 4=$ moderate $(6 \%$ to $15 \%)$, $6=$ severe $(16 \%$ to $75 \%)$, and $8=$ very severe $(>75 \%)$. Measurements were made 0,2, 4, and 6 days after transfer to 20C.

Measurement of ethylene and $\mathrm{CO}_{2}$ production. Production of $\mathrm{C}_{2} \mathrm{H}_{4}$ and $\mathrm{CO}_{2}$ were calculated from an analysis of 1-ml samples of the head space gas accumulated in 4-liter glass jars (Saltveit and McFeeters, 1980). Three replicates of three fruit were used in each determination. Rates of $\mathrm{C}_{2} \mathrm{H}_{4}$ and $\mathrm{CO}_{2}$ production were calculated from measurements taken at 2.5, 12.5, and 20C.

Measurement of ion leakage. Epidermal mesocarp disks were excised with a stainless steel cork borer from the central region of each fruit, trimmed of seed cavity tissue to $4 \mathrm{~mm}$ thickness with a stainless steel razor blade, and washed for $1 \mathrm{~min}$ in two changes of $20 \mathrm{ml}$ deionized water. Three 4-mm-thick $\times 9$-mmdiameter disks, weighing a total of $\approx 1 \mathrm{~g}$, were incubated in a 100 -ml beaker containing $30 \mathrm{ml}$ of $0.3 \mathrm{~m}$ mannitol and shaken at 100 cycles per min. Conductivity measurements were taken with an Extech Conductivity Meter Model 480 (Waltham, Mass.) 0.5 and $1 \mathrm{hr}$ after adding the mannitol. Preliminary experiments had shown that, after a nonlinear increase for the first 20 rein, the conductivity of the mannitol solution increased linearly for up to $3 \mathrm{hr}$ from both chilled and nonchilled disks (data not shown). The beakers containing the tissue and mannitol were weighed and the contents boiled for $5 \mathrm{~min}$. After cooling to room temperature, weights were adjusted to the original weights with deionized water and total conductivity was measured after $30 \mathrm{~min}$ of shaking. To compensate for differences among the samples, results are expressed in terms of relative leakage; i.e., the change in conductivity of the solution during the 1-hr sampling period as a percent of the conductivity of the solution after boiling.

Determining EFE activity and ACC content. The EFE activity and ACC content were also analyzed in washed $4 \times 9-\mathrm{mm}-$ diameter epidermal mesocarp disks. For the determination of EFE activity, disks were placed epidermis down in $15 \times 60$ $\mathrm{mm}$ plastic petri dishes and $10 \mu \mathrm{l}$ of deionized water or $10 \mu \mathrm{M}$ ACC was applied to each disk. After $6 \mathrm{hr}$, four disks from each treatment were blotted dry and transferred to $16 \times 100$-mm test tubes that were capped with rubber serum stoppers. After $1 \mathrm{hr}$ of incubation, a l-ml sample of the headspace gas was withdrawn and injected in a Carle (Loveland, Colo.) gas chromatograph with a flame ionization detector to quantitate the $\mathrm{C}_{2} \mathrm{H}_{4}$ produced. EFE activity was calculated as the difference between $\mathrm{C}_{2} \mathrm{H}_{4}$ production with and without ACC.

ACC was extracted from three disks in $10 \mathrm{ml}$ of $90 \%$ ethanol in a tared $16 \times 100-\mathrm{mm}$ test tube for $7 \mathrm{hr}$ at $70 \mathrm{C}$, and assayed as reported by Lizada and Yang (1979).

\section{Results}

Pitting and decay. Pitting and decay were observed neither on the control fruit held at $12.5 \mathrm{C}$ nor on the intermittently warmed fruit, either during the 13-day temperature treatment or during 6 additional days of storage at 20C (Table 1). In contrast, continuously chilled fruit developed slight pitting (i.e., a score of 1) after 13 days of chilling. The severity of pitting increased to
Table 1. Pitting and decay of cucumber fruit stored for 13 days at $2.5 \mathrm{C} .^{\mathrm{z}}$

\begin{tabular}{ccc}
\hline \hline \multirow{2}{*}{$\begin{array}{l}\text { Additional } \\
\text { days at 20C }\end{array}$} & Pitting & Defect ${ }^{y}$ \\
\hline 0 & 1.0 & Decay \\
2 & $4.2 *$ & 0.0 \\
4 & $7.3 *$ & 0.0 \\
6 & $7.9 *$ & $2.6 *$ \\
\hline
\end{tabular}

${ }^{2}$ The incidence of pitting and decay was determined subjectively by an 8 -point Hedonic scale, where $0=$ no pitting or decay $(0 \%$ of the surface covered), $2=$ slight $(1 \%$ to $5 \%), 4=$ moderate $(6 \%$ to $15 \%)$, $6=$ severe $(16 \%$ to $75 \%)$, and $8=$ very severe $(>75 \%$ of the surface covered). Pitting and decay were absent in fruit held continuously at $12.5 \mathrm{C}$ or intermittently warmed from 2.5 to $12.5 \mathrm{C}$ for $18 \mathrm{hr}$ every 2 or 3 days.

'Means were separated within columns by using Dunnett's test $(P=$ $0.05, *)$ to compare each longer period with zero time.

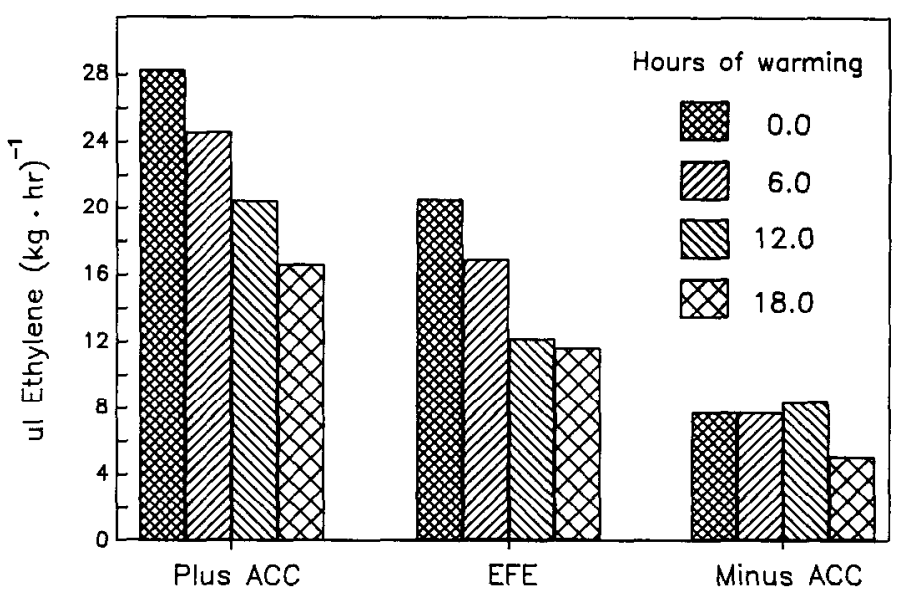

Fig. 1. Ethylene-forming enzyme activity (EFE) of chilled cucumber fruit with intermittent warming. The fruit were chilled at $2.5 \mathrm{C}$ for 11 days with $0,6,12$, or $18 \mathrm{hr}$ of warming to $12.5 \mathrm{C}$ after 5 days of chilling. EFE activity is expressed as the difference between $\mathrm{C}_{2} \mathrm{H}_{4}$ production with and without added ACC. Comparison by Dunnet's test, $P=0.05$. Plus ACC, EFE-all differ from $0 \mathrm{hr}$; minus ACC, only $18 \mathrm{hr}$ differs from $0 \mathrm{hr}$.

moderate (4.2) and very severe (7.9) after the chilled fruit had been warmed at 20C for 2 and 6 days, respectively. Fungus, which was identified as Aspergillus sp. (black mold), was observed in pitted areas after 2 days at 20C only on fruit that had been continuously chilled at $2.5 \mathrm{C}$ for 13 days.

EFE activity of intermittently warmed fruit. The level of EFE activity measured after 11 days of chilling at $2.5 \mathrm{C}$ was significantly lower for fruit that had the chilling period interrupted after 5 days by warming to $12.5 \mathrm{C}$ for 6,12 , or $18 \mathrm{hr}$ than for fruit continuously chilled (Fig. 1). Fruit that were not warmed had almost twice as much EFE activity as did the fruit warmed for 12 or $18 \mathrm{hr}$; i.e., activities of 21 and $11 \mu \mathrm{C}_{2} \mathrm{H}_{4} /(\mathrm{kg} \cdot \mathrm{hr})$, respectively. In subsequent intermittent warming experiments, warming periods of $18 \mathrm{hr}$ were used.

Ethylene production. The rate of $\mathrm{C}_{2} \mathrm{H}_{4}$ production remained between 5 and $10 \mathrm{nl} \cdot(\mathrm{kg} \cdot \mathrm{hr})^{-1}$ and between 10 and $20 \mathrm{nl} \cdot(\mathrm{kg} \cdot \mathrm{hr})^{-1}$ for fruit held continuously at 2.5 or $12.5 \mathrm{C}$, respectively (Fig. 2). Warming fruit to $12.5 \mathrm{C}$ after $72 \mathrm{hr}$ at $2.5 \mathrm{C}$ resulted in a rapid 18-fold increase in the rate of $\mathrm{C}_{2} \mathrm{H}_{4}$ production from 5.4 to $95.5 \mathrm{nl} \cdot(\mathrm{kg} \cdot \mathrm{hr})^{-1}$ within $18 \mathrm{hr}$ of warming. Cooling these 


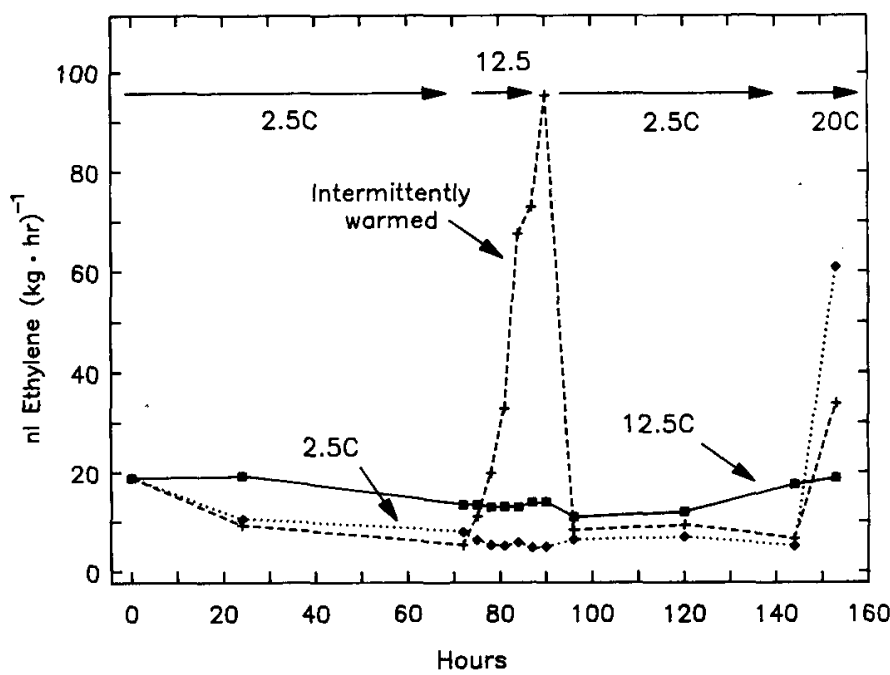

Fig. 2. Effect of intermittent warming on $\mathrm{C}_{2} \mathrm{H}_{4}$ production of cucumber fruit. The fruit were either held continuously at 2.5 or $12.5 \mathrm{C}$ for $144 \mathrm{hr}$, or held at $2.5 \mathrm{C}$ for $72 \mathrm{hr}, 12.5 \mathrm{C}$ for an additional $18 \mathrm{hr}$, and then at $2.5 \mathrm{C}$ for the remainder of the 144-hr treatment period. All fruit were warmed to $20 \mathrm{C}$ after $144 \mathrm{hr}$. Vertical error bars representing the SE of the mean are contained within the symbols.

fruit to $2.5 \mathrm{C}$ was quickIy followed by a reduction in the rate of $\mathrm{C}_{2} \mathrm{H}_{4}$ production from 95.5 to $8.5 \mathrm{nl} \cdot(\mathrm{kg} \cdot \mathrm{hr})^{-1}$ within $6 \mathrm{hr}$ of cooling. After 6 days (i. e., $144 \mathrm{hr}$ ), the rate of $\mathrm{C}_{2} \mathrm{H}_{4}$ production had started to increase in the fruit continuously held at $12.5 \mathrm{C}$. This increase coincided with yellowing and appearance of fungi on some fruit.

All fruit were transferred to 20C after $144 \mathrm{hr}$. Substantial increases in the rate of $\mathrm{C}_{2} \mathrm{H}_{4}$ production from 5.2 to $61 \mathrm{nl} \cdot(\mathrm{kg} \cdot \mathrm{hr})^{-1}$ and from 6.7 to $35 \mathrm{nl} \cdot(\mathrm{kg} \cdot \mathrm{hr})^{-1}$ were observed $9 \mathrm{hr}$ after the continuously chilled and intermittently warmed fruit, respectively, were transferred to 20C (Fig. 2). There was only a slight rise in the rate of $\mathrm{C}_{2} \mathrm{H}_{4}$ production when the fruit continuously held at $12.5 \mathrm{C}$ were transferred to $20 \mathrm{C}$. The rate of $\mathrm{C}_{2} \mathrm{H}_{4}$ production from all the fruit continued to increase, reaching 371 , 156 , and $35 \mathrm{nl} \cdot(\mathrm{kg} \cdot \mathrm{hr})^{-1}$ after $24 \mathrm{hr}$ at $20 \mathrm{C}$ for the $2.5 \mathrm{C}$, intermittently warmed, and $12.5 \mathrm{C}$ fruit, respectively.

Experiments with multiple cycles of warming were performed next. The rate of $\mathrm{C}_{2} \mathrm{H}_{4}$ production from control fruit that were continuously held at $12.5 \mathrm{C}$ doubled during the 13 -day experiment (Table 2). It slowly increased from 17.5 to between 31 and $36 \mathrm{nl} \cdot(\mathrm{kg} \cdot \mathrm{hr})^{-1}$ during the $320-\mathrm{hr}$ storage period at $12.5 \mathrm{C}$. The average rate of production during this period was $30 \pm 12$ $\mathrm{nl} \cdot(\mathrm{kg} \cdot \mathrm{hr})^{-1}$. As in the previous experiments with one warming cycle, $\mathrm{C}_{2} \mathrm{H}_{4}$ production remained around $34 \pm 3 \mathrm{nl} \cdot(\mathrm{kg} \cdot \mathrm{hr})^{-1}$ during 2 subsequent days of storage at $20 \mathrm{C}$ for the fruit that had been continuously held at $12.5 \mathrm{C}$.

Low rates of $\mathrm{C}_{2} \mathrm{H}_{4}$ production were also observed during the first $170 \mathrm{hr}$ ( $\approx 7$ days) of continuous storage at $2.5 \mathrm{C}$ (Table 2). When sampled after $\approx 10$ days at the end of the third chilling cycle (i.e., $230 \mathrm{hr}$ ) or at the end of the third warming cycle (i.e., $248 \mathrm{hr}$ ) however, the rate of $\mathrm{C}_{2} \mathrm{H}_{4}$ production had increased around 2 -fold to $36 \mathrm{nl} \cdot(\mathrm{kg} \cdot \mathrm{hr})^{-1}$, and then increased an additional $20 \%$ to around $44 \mathrm{nl} \cdot(\mathrm{kg} \cdot \mathrm{hr})^{-1}$ during the $320-\mathrm{hr}(\approx 13$ days) sampling period. The increased production of $\mathrm{C}_{2} \mathrm{H}_{4}$ after 9 days $(230 \mathrm{hr})$ of continuous chilling is similar to the increase in $\mathrm{CO}_{2}$ production previously reported (Mack and Janer, 1942; Eaks and Morris, 1956). A dramatic 12.5-fold increase in $\mathrm{C}_{2} \mathrm{H}_{4}$ production to $554 \mathrm{nl} \cdot(\mathrm{kg} \cdot \mathrm{hr})^{-1}$ occurred when the continuously chilled fruits were transferred from $2.5 \mathrm{C}$ to $20 \mathrm{C}$ after 13 days. Ethylene production declined to $52 \mathrm{nl} \cdot(\mathrm{kg} \cdot \mathrm{hr})^{-1}$ after an additional day at 20C; a level of production significantly higher than that during the last measurement at $2.5 \mathrm{C}$.

Fruit in all three temperature treatments had similar rates of $\mathrm{C}_{2} \mathrm{H}_{4}$ production after $55 \mathrm{hr}$; these rates had not changed significantly after $73 \mathrm{hr}$ for the chilled and control fruit. In contrast, warming fruit to $12.5 \mathrm{C}$ at $73 \mathrm{hr}$ resulted in an almost 20-fold increase in $\mathrm{C}_{2} \mathrm{H}_{4}$ production. The increased rate of $\mathrm{C}_{2} \mathrm{H}_{4}$ production during the first warming period from $12 \mathrm{nl} \cdot(\mathrm{kg} \cdot \mathrm{hr})^{-1}$ at $2.5 \mathrm{C}$ to $201 \mathrm{nl} \cdot(\mathrm{kg} \cdot \mathrm{hr})^{-1}$ at $12.5 \mathrm{C}$ was significantly greater than during the second or third warming periods; 53 to 98 , and 53 to $55 \mathrm{nl} \cdot(\mathrm{kg} \cdot \mathrm{hr})^{-1}$, respectively. The $\mathrm{Q}_{10}$ of the increase in $\mathrm{C}_{2} \mathrm{H}_{4}$ production upon warming 10 degrees from 2.5 to 12.5 was around 17 for the first warming period and 1.8 and 1.1 during the two subsequent warming periods. Rates of $\mathrm{C}_{2} \mathrm{H}_{4}$ production were similar for both chilled and intermittently warmed fruit at $320 \mathrm{hr}$ and again after 2 days at 20C.

Respiration rate. Low respiration rates, $\approx 10$ to $20 \mathrm{mg} \mathrm{CO}_{2} /$ $(\mathrm{kg} \cdot \mathrm{hr})$, were measured from fruit continuously held at $12.5 \mathrm{C}$, while rates of 7 to $9 \mathrm{mg} \cdot(\mathrm{kg} \cdot \mathrm{hr})^{-1}$ were measured from fruit continuously chilled at $2.5 \mathrm{C}$ (Table 2 ). Since the measurements were made at 12.5 and $2.5 \mathrm{C}$, respectively, a 2-fold difference in respiration rates was expected. The $\mathrm{Q}_{10}$ during the 13-day storage period ranged from 1.2 to 2.2 , with an average of 1.8 \pm 0.4 between the fruit continuously held at 2.5 and $12.5 \mathrm{C}$.

Carbon dioxide production by intermittently warmed fruit increased as the fruit were warmed from 2.5 to $12.5 \mathrm{C}$. The rate of $\mathrm{CO}_{2}$ production at $2.5 \mathrm{C}$ (i.e., at the end of each chilling period) steadily increased from 7.9 to $11.7 \mathrm{mg} \cdot(\mathrm{kg} \cdot \mathrm{hr})^{-1}$ during the first $230 \mathrm{hr}$ of the experiment, before declining to 7.3 $\mathrm{mg} \cdot(\mathrm{kg} \cdot \mathrm{hr})^{-1}$ at the end of the last chilling period. The respiration rate after $320 \mathrm{hr}$ was similar for the chilled and intermittently warmed fruit and, as expected with a $Q_{10}$ of 2 , about double for the control fruit at $12.5 \mathrm{C}$.

The rate of $\mathrm{CO}_{2}$ production increased 3-fold during the first warming period, but only increased around 2-fold during the two subsequent warming periods. All fruit showed increased respiration when warmed at $20 \mathrm{C}$.

Ion leakage. The rate of ion leakage from mesocarp disks excised from fruit continuously held at $12.5 \mathrm{C}$ remained at $\approx 6 \%$ of the total ions per hour during the entire $12.5 \mathrm{C}$ storage period, while it fluctuated between $6 \%$ and $9 \%$ for fruit kept at $2.5 \mathrm{C}$ for $169 \mathrm{hr}$ (Fig. 3). From $230 \mathrm{hr}$ on, the rate of ion leakage remained substantially different for each temperature treatment. It had increased to between $8.5 \%$ and $11 \%$ for intermittently warmed fruit and to between $16 \%$ and $18 \%$ for continuously chilled fruit. Ion leakage increased only minimally when either fruit continuously held at $12.5 \mathrm{C}$ or intermittently warmed fruit were transferred to 20C. In contrast, ion leakage from chilled tissue rose substantially, from $17 \%$ to $23 \%$, upon warming.

EFE activity. The EFE activity of fruit continuously held at $12.5 \mathrm{C}$ showed a variable, but slowly increasing, rate of activity from 23 to around $40 \mu \mathrm{C}_{2} \mathrm{H}_{4} /(\mathrm{kg} \cdot \mathrm{hr})$ during the $320 \mathrm{hr}$ (13 days) of the experiment (Table 3 ). In contrast, fruit continuously chilled at $2.5 \mathrm{C}$ showed a brief increase in activity at $55 \mathrm{hr}$ from 23 to $43 \mu \mathrm{l} \mathrm{C}_{2} \mathrm{H}_{4}(\mathrm{~kg} \cdot \mathrm{hr})$, before starting a steady decline in activity to $6.4 \mu \mathrm{C}_{2} \mathrm{H}_{4} /(\mathrm{kg} \cdot \mathrm{hr})$, which continued even after transfer to $20 \mathrm{C}$.

EFE activity of intermittently warmed fruit during their first chilling cycle was similar to fruit held continuously at $2.5 \mathrm{C}$. At 
Table 2. Ethylene production and respiration rates of cucumber fruit stored at $2.5 \mathrm{C}, 12.5 \mathrm{C}$, and intermittently warmed (IW). IW fruit were held $2.5 \mathrm{C}$ and warmed to $12.5 \mathrm{C}$ for $18 \mathrm{hr}$ every 2 to 3 days. Chilling and warming cycles refer to the IW fruit. ${ }^{z}$

\begin{tabular}{|c|c|c|c|c|c|c|c|c|}
\hline \multirow{2}{*}{ Cycle } & \multirow{2}{*}{$\begin{array}{c}\text { Time of } \\
\text { measurement }\end{array}$} & \multirow{2}{*}{$\begin{array}{c}\text { Total } \\
\mathrm{hr}\end{array}$} & \multicolumn{3}{|c|}{$\mathrm{nl} \mathrm{C}_{2} \mathrm{H}_{4} /(\mathrm{kg} \cdot \mathrm{hr})$} & \multicolumn{3}{|c|}{$\mathrm{mg} \mathrm{CO} /(\mathrm{kg} \cdot \mathrm{hr})$} \\
\hline & & & $2.5 \mathrm{C}$ & $12.5 \mathrm{C}$ & $I^{y}$ & $2.5 \mathrm{C}$ & $12.5 \mathrm{C}$ & IW $^{y}$ \\
\hline 0 & No chilling & 0 & & $18 \mathrm{j}$ & & & $19 \mathrm{de}$ & \\
\hline \multirow[t]{2}{*}{1} & End of chilling ${ }^{x}$ & 55 & $12 \mathrm{j}$ & $20 \mathrm{ij}$ & $12 \mathrm{j}$ & $9.1 \mathrm{~g}$ & $17 \mathrm{e}$ & $9 \mathrm{~g}$ \\
\hline & End of warmingw & 73 & $16 j$ & $15 \mathrm{j}$ & $201 \mathrm{~b}$ & $8.2 \mathrm{~g}$ & $13 \mathrm{f}$ & $25 \mathrm{C}$ \\
\hline \multirow[t]{2}{*}{2} & End of chilling ${ }^{\mathrm{x}}$ & 148 & $19 \mathrm{ij}$ & $27 \mathrm{hi}$ & $53 \mathrm{e}$ & $8.5 \mathrm{~g}$ & $13 \mathrm{f}$ & $10 \mathrm{~g}$ \\
\hline & End of warmingw & 169 & $16 \mathrm{j}$ & $26 \mathrm{i}$ & $98 \mathrm{c}$ & $8.9 \mathrm{~g}$ & $10 \mathrm{fg}$ & $18 \mathrm{e}^{\mathrm{5}}$ \\
\hline \multirow[t]{2}{*}{3} & End of chilling ${ }^{x}$ & 230 & $35 \mathrm{~g}$ & $34 \mathrm{gh}$ & $53 \mathrm{e}$ & $9.2 \mathrm{~g}$ & $17 e^{6}$ & $12 \mathrm{f}$ \\
\hline & End of warmingw & 248 & $37 \mathrm{fg}$ & $35 \mathrm{~g}$ & $55 \mathrm{e}$ & $8.3 \mathrm{~g}$ & $18 \mathrm{e}$ & $22 \mathrm{~cd}$ \\
\hline \multirow[t]{3}{*}{4} & End of chilling & 320 & $44 \mathrm{f}$ & $31 \mathrm{~h}$ & $45 \mathrm{f}$ & $7.3 \mathrm{~g}$ & $16 \mathrm{e}$ & $7 \mathrm{~g}$ \\
\hline & 1 day at $20 \mathrm{C}^{\circ}$ & 344 & $554 \mathrm{a}$ & $36 \mathrm{~g}$ & $78 \mathrm{~d}$ & $54 \mathrm{a}$ & $32 \mathrm{~b}$ & $53 \mathrm{a}$ \\
\hline & 2 days at $20 \mathrm{C}^{\circ}$ & 368 & $52 \mathrm{e}$ & $31 \mathrm{~h}$ & $41 \mathrm{fg}$ & & & \\
\hline
\end{tabular}

${ }^{2}$ Means separation within $\mathrm{C}_{2} \mathrm{H}_{4}$ and $\mathrm{CO}_{2}$ production are by Duncan's multiple range test, $P=0.05$.

${ }^{y}$ The $\mathrm{C}_{2} \mathrm{H}_{4}$ and $\mathrm{CO}_{2}$ production of IW fruit were measured at $2.5 \mathrm{C}\left({ }^{\mathrm{x}}\right), 12.5 \mathrm{C}\left({ }^{\mathrm{w}}\right)$, or $20 \mathrm{C}\left({ }^{v}\right)$.

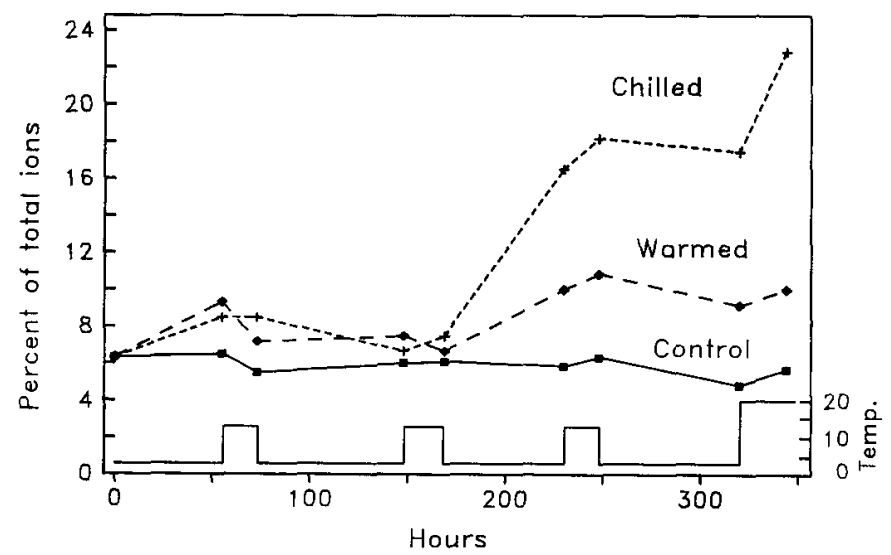

Fig. 3. Effect of chilling and intermittent warming on ion leakage from $4 \times 9$-mm-thick disks excised from cucumber fruit held at 2.5 (chilled) or $12.5 \mathrm{C}$ (control) for $320 \mathrm{hr}$. Fruit held at $2.5 \mathrm{C}$ were warmed to $12.5 \mathrm{C}$ for around $18 \mathrm{hr}$ every 2 to 3 days (warmed).

the end of chilling in the second cycle, however, EFE activity of intermittently warmed fruit was significantly lower than continuously chilled fruit, and both values were significantly lower than fruit continuously held at $12.5 \mathrm{C}$ (Table 3 ). Warming fruit to $12.5 \mathrm{C}$ from 148 to $169 \mathrm{hr}$ caused no significant change in EFE activity, while there was a marked, unaccountable rapid decline in the EFE activity in fruit continuously chilled at 2.5C. Rates of EFE activity remained elevated in intermittently warmed fruit during the third cycle, finally reaching a level of activity similar to fruit continuously held at $12.5 \mathrm{C}$ by the end of the fourth chilling cycle. Upon warming to 20C, however, the EFE activity of intermittently warmed fruit rapidly declined to levels of activity similar to the continuously chilled fruit. In contrast, the rate increased in fruit continuously held at $12.5 \mathrm{C}$ from 28.2 $\mu \mathrm{C}_{2} \mathrm{H}_{4} /(\mathrm{kg} \cdot \mathrm{hr})$ at the end of the fourth chilling cycle to $39 \mu \mathrm{l}$ $\mathrm{C}_{2} \mathrm{H}_{4}(\mathrm{~kg} \cdot \mathrm{hr})$ after 1 day at $20 \mathrm{C}$.

ACC content. The level of ACC in fruit continuously held at $12.5 \mathrm{C}$ was variable, but averaged $\approx 1 \quad 0.2 \pm 0.1 \mathrm{nmol} \cdot \mathrm{g}^{-1}$ (fresh weight) during the experiments (Table 3). During the first 169 $\mathrm{hr}$, fruit continuously held at $2.5 \mathrm{C}$ had levels of ACC similar to the fruit held at $12.5 \mathrm{C}$. ACC content of chilled fruit dramatically increased > 10 -fold to $1.8 \mathrm{nmol} \cdot \mathrm{g}^{-1}$ (fresh weight) by
$248 \mathrm{hr}$, and > 40-fold to $6.2 \mathrm{nmol} \cdot \mathrm{g}^{-1}$ (fresh weight) by 320 hr. In contrast, ACC levels in intermittently warmed fruit increased slightly more than 3-fold during the first and second warming periods. The levels of ACC in intermittently warmed fruit appeared to stabilize at around $0.50 \mathrm{nmol} \cdot \mathrm{g}^{-1}$ (fresh weight) for the duration of the experiment.

\section{Discussion}

Pitting and increased decay are two visible symptoms of chilling injury in cucumber fruit that were alleviated by interrupting the period of exposure to chilling at $2.5 \mathrm{C}$ with 18 -hr periods of intermittent warming at $12.5 \mathrm{C}$ every 2.5 to 3 days for $\approx 13$ days (Table 1). The physiological responses of increased $\mathrm{C}_{2} \mathrm{H}_{4}$ production and ion leakage that are also associated with chilling injury were reduced by this intermittent warming treatment (Table 2, Fig. 3). Another indicator of chilling injury, increased $\mathrm{CO}_{2}$ production, however, was not reduced by intermittent warming (Table 2). The lack of a significant correlation between $\mathrm{CO}_{2}$ and $\mathrm{C}_{2} \mathrm{H}_{4}$ production implies that the increase in $\mathrm{CO}_{2}$ production was not induced by the increase in $\mathrm{C}_{2} \mathrm{H}_{4}$ production.

The two visual symptoms of chilling injury are probably interrelated, in that the breakdown of tissue that results in formation of pits would also provide a suitable environment for the growth of the weak saprophytic pathogens that colonize chilled cucumber fruit. Physiological responses to attack by pathogens may also be curtailed by chilling, but this aspect was not investigated.

The increase in ion leakage following chilling is probably an early manifestation of the collapse of tissue that produced the visual symptoms. However, a significant increase in the rate of ion leakage measured within a few hours of removal from chilling was not observed until after $170 \mathrm{hr}$ ( $\approx 7$ days) of continuous chilling, while increased pitting and decay after 4 days at 20C were observed after only 5 days of chilling (Cabrera and Saltveit, 1989). Obviously, sufficient damage had occurred after 4 days of chilling to result in the subsequent development of visual symptoms, while almost twice that length of exposure was necessary to produce effects on membrane permeability that could be measured as increased ion leakage immediately after chilling. Alteration in this gross measurement of membrane permeability, therefore, appears to be one of the results, rather than the immediate cause, of chilling injury in cucumber fruit. 
Table 3. Ethylene-forming enzyme (EFE) activity and ACC content of cucumber fruit stored at 2.5C, $12.5 \mathrm{C}$, and intermittently warmed (IW). IW fruit were held at $2.5 \mathrm{C}$ and warmed to $12.5 \mathrm{C}$ for 18 hr every 2 to 3 days. The EFE activity was measured at $20 \mathrm{C}{ }^{z}$

\begin{tabular}{|c|c|c|c|c|c|c|c|c|}
\hline \multirow[b]{3}{*}{ Cycle } & \multirow{3}{*}{$\begin{array}{c}\text { Time of } \\
\text { measurement }\end{array}$} & \multirow{3}{*}{$\begin{array}{c}\text { Total } \\
\mathrm{hr}\end{array}$} & \multicolumn{3}{|c|}{ EFE } & \multicolumn{3}{|c|}{$\mathrm{ACC}$} \\
\hline & & & \multicolumn{3}{|c|}{$\mu \mathrm{l} \mathrm{C}_{2} \mathrm{H}_{4} /(\mathrm{kg} \cdot \mathrm{hr})$} & \multicolumn{3}{|c|}{$\mathrm{nmol}^{-\mathrm{g}^{-1}}$ (fresh wt) } \\
\hline & & & $2.5 \mathrm{C}$ & $12.5 \mathrm{C}$ & IWy & $2.5 \mathrm{C}$ & $12.5 \mathrm{C}$ & IW $^{y}$ \\
\hline 0 & No chilling & 0 & & $23 \mathrm{c}$ & & & $0.25 \mathrm{f}$ & \\
\hline \multirow[t]{2}{*}{1} & End of chilling ${ }^{x}$ & 55 & $43 \mathrm{a}$ & $23 \mathrm{c}$ & $39 a$ & $0.23 \mathrm{f}$ & $0.23 \mathrm{f}$ & $0.15 \mathrm{fg}$ \\
\hline & End of warmingw & 73 & - &.- & -.- & $0.24 \mathrm{f}$ & $0.37 \mathrm{e}$ & $0.50 \mathrm{~d}$ \\
\hline \multirow[t]{2}{*}{2} & End of chilling ${ }^{\mathbf{x}}$ & 148 & $25 \mathrm{c}$ & $30 \mathrm{~b}$ & $15 \mathrm{e}$ & $0.16 \mathrm{fg}$ & $0.16 \mathrm{fg}$ & $0.20 \mathrm{fg}$ \\
\hline & End of warmingw & 169 & $13 \mathrm{f}$ & $24 \mathrm{c}$ & $15 \mathrm{e}$ & $0.14 \mathrm{fg}$ & $0.11 \mathrm{~g}$ & $0.74 \mathrm{c}$ \\
\hline \multirow[t]{2}{*}{3} & End of chilling & 230 & -.. & - & ... & - & -.. & -.. \\
\hline & End of warming & 248 & $6.4 \mathrm{~g}$ & $40 a$ & $18 \mathrm{~cd}$ & $1.8 \mathrm{~b}$ & $0.09 \mathrm{~g}$ & $0.54 \mathrm{~d}$ \\
\hline \multirow[t]{2}{*}{4} & End of chilling ${ }^{\mathrm{x}}$ & 320 & $6.4 \mathrm{~g}$ & $28 \mathrm{~b}$ & $21 \mathrm{~b}$ & $6.2 \mathrm{a}$ & $0.14 \mathrm{fg}$ & $0.49 \mathrm{~d}$ \\
\hline & 1 day at $20 \mathrm{C}^{\mathrm{v}}$ & 344 & $1.0 \mathrm{~h}$ & $39 \mathrm{a}$ & $3.6 \mathrm{gh}$ & -.- & -.. & $\ldots$ \\
\hline
\end{tabular}

${ }^{2}$ Means separation within EFE and ACC are by Duncan's multiple range test, $P=0.05$.

${ }^{y} \mathrm{The} \mathrm{C}_{2} \mathrm{H}_{4}$ and $\mathrm{CO}_{2}$ production of intermittently warmed fruit were measured at $2.5 \mathrm{C}\left({ }^{\mathrm{x}}\right), 12.5 \mathrm{C}\left({ }^{\mathrm{w}}\right)$, or $20 \mathrm{C}(v)$.

Our regime of intermittent warming did not prevent the chillinduced increase in ion leakage, but did reduce the rate of increase to about one-half that of continuously chilled fruit (Fig. 3 ). While this lower rate was still almost twice that of fruit held at $12.5 \mathrm{C}$, the treatment was sufficient to completely prevent the development of either pitting or decay in fruit held for an additional 6 days at $20 \mathrm{C}$ after chilling (Table 1). Intermittently warmed fruit were apparently able to overcome the moderate level of chilling injury that produced a doubling of leakage.

The most pronounced effects of intermittent warming were the large bursts of $\mathrm{C}_{2} \mathrm{H}_{4}$ production during the first warming period, and the decrease in the intensity of this burst at the subsequent warming periods. The burst in $\mathrm{C}_{2} \mathrm{H}_{4}$ production could result from an increase in the activity of the EFE, an increase in the substrate for $\mathrm{C}_{2} \mathrm{H}_{4}$ production, or a decrease in the compartmentalization of the reactants.

Chill-induced $\mathrm{C}_{2} \mathrm{H}_{4}$ production was not significantly correlated with increased EFE activity. While 3 days of chilling actually stimulated EFE activity, longer exposures to $2.5 \mathrm{C}$ resulted in the loss of EFE activity (Table 3). These results support those of Wang and Adams (1980), who reported that prolonged chilling damages the system that converts ACC to $\mathrm{C}_{2} \mathrm{H}_{4}$. The decline in EFE activity in intermittently warmed fruit was generally less than that measured in continuously chilled fruit, while fruit held at $12.5 \mathrm{C}$ had slightly increasing EFE activities during the experiment. Since the EFE is thought to be membrane-bound, and increased ion leakage indicated that membrane damage was occurring during prolonged exposure to chilling temperatures, it is not surprising that EFE activity of continuously chilled fruit started to decline below the control level (Table 3) at the same time $(\approx 170 \mathrm{hr})$ that the rate of ion leakage started to increase (Fig. 3).

ACC levels were also not significantly correlated with chillinduced $\mathrm{C}_{2} \mathrm{H}_{4}$ production in continuously chilled or intermittently warmed fruit. While ACC levels of intermittently warmed cucumbers increased 3-fold during the first two warming cycles, the increase $\mathrm{In}_{2} \mathrm{H}_{4}$ production was around 20-fold and 2-fold during the first and second cycles, respectively (Tables 2 and 3 ). The correlation between ACC levels and $\mathrm{C}_{2} \mathrm{H}_{4}$ production by intermittently warmed fruit was not significant $(r=0.53)$. It is clear that synthesis of the substrate for $\mathrm{C}_{2} \mathrm{H}_{4}$ production, i.e., ACC, is stimulated by prolonged chilling and by transfer to warming temperatures (Table 3 ). Increased ACC levels were found in intermittently warmed fruit after each warming and in continuously chilled fruit after $230 \mathrm{hr}$. Our results agree with those of Wang and Adams (1982) that the conversion of ACC to $\mathrm{C}_{2} \mathrm{H}_{4}$, rather than the availability of the substrate, appears to be the limiting factor in the production of chill-induced $\mathrm{C}_{2} \mathrm{H}_{4}$ production.

The first burst in $\mathrm{C}_{2} \mathrm{H}_{4}$. production following warming could have resulted from a combination of the $70 \%$ increase in EFE activity and the 3 -fold increase in ACC concentration (Table 3). However, the subsequent much smaller 2-fold increase in $\mathrm{C}_{2} \mathrm{H}_{4}$ production during the second warming cycle when EFE activity remained constant and ACC level increased 3.7-fold, and the lack of any increase in $\mathrm{C}_{2} \mathrm{H}_{4}$ production during the third warming cycle when both EFE activity and ACC content were elevated over that of the second cycle, are inconsistent with this explanation.

The conversion of $\mathrm{ACC}$ to $\mathrm{C}_{2} \mathrm{H}_{4}$ is not the only limiting factor in chill-induced $\mathrm{C}_{2} \mathrm{H}_{4}$ production-some other restriction must apply because chill-induced $\mathrm{C}_{2} \mathrm{H}_{4}$ production is not significantly correlated with either EFE activity or ACC content in any of the temperature treatments. If the three factors of ACC content, EFE activity, and membrane permeability are considered together, no significant correlation exists between them and $\mathrm{C}_{2} \mathrm{H}_{4}$ production, except for the intermittent warming treatment. Fruit continuously held at $2.5 \mathrm{C}$ and $12.5 \mathrm{C}$ had correlation coefficients between $\mathrm{C}_{2} \mathrm{H}_{4}$ production and the three factors of 0.27 and 0.51 , respectively. The regression line calculated for the $12.5 \mathrm{C}$ treatment had a negative slope, indicating that $\mathrm{C}_{2} \mathrm{H}_{4}$ production was negatively correlated with the three factors. In comparison, intermittently warmed fruit had a significant correlation coefficient of 0.86 between $\mathrm{C}_{2} \mathrm{H}_{4}$ production and the product of EFE activity times ACC content divided by the rate of ion leakage.

Interrupting a period of chilling with a period of warming at nonchilling temperatures appears to allow the tissue to acclimate to chilling temperatures, as is shown by the reduced production of $\mathrm{C}_{2} \mathrm{H}_{4}$ at each progressive warming period. The chill-induced increases in ACC content, EFE activity, and membrane permeability were diminished by successive chilling and warming periods. Periodic warming appears to allow chilled fruit to acclimate 
to subsequent periods of chilling. The method by which intermittent warming accomplishes these physiological changes requires further study.

\section{Literature Cited}

Anderson, R.E. 1982. Long-term storage of peaches and nectarines intermittently warmed during controlled atmosphere storage. J. Amer. Soc. Hort. Sci. 107:214-216.

Cabrera, R.M. and M.E. Saltveit, Jr. 1989. Effects of intermittent warming on the chilling injury of cucumber fruits, In: Intl. Conf. Tech. Innovations in Freezing and Refrigeration of Fruit and Vegetables. 9-12 July. Univ. of California, Davis. (In press.)

Davis, P.L. and R.C. Hofmann. 1973. Reduction of chilling injury of citrus fruits in cold storage by intermittent warming. J. Food Sci. 38:871-873.

Eaks, I.L. 1965. Effect of chilling on the respiration of oranges and lemons. Proc. Amer. Soc. Hort. Sci. 87:181-186.

Eaks, I.L. and L.L. Morris. 1956. Respiration of cucumber fruits associated with physiological injury at chilling temperatures. Plant Physiol. 31:308-314.

Eaks, I.L. and L.L. Morris. 1957. Deterioration of cucumbers at chilling and non-chilling temperatures. Proc. Amer. Soc. Hort. Sci. 69:388-399.

Hirose, T. 1985. Effects of pre- and interposed warming on chilling injury, respiratory rate and membrane permeability of cucumber fruits during cold storage. J. Jpn. Soc. Hort. Sci. 53:459-466.

Hrushcka, H.W., W.L. Smith, and J.E. Baker. 1968. Reducing chilling injury of potatoes by intermittent warming. Amer. Potato J. 46:38-53.

Ilker, Y. 1976. Physiological manifestation of chilling injury and its alleviation in okra fruits (Abelmoschus. esculentus L.). PhD Diss. Univ. of California, Davis.

Lizada, M.C.C. and S.F. Yang. 1979. A simple and sensitive assay for 1-aminocyclopropane-1-carboxylic acid. Anal. Biochem. 100:140145.
Lyons, J.M. 1973. Chilling injury in plants. Annu. Rev. Plant Physiol. 24:445-466.

Mack, W.B. and J.R. Janer. 1942. Effects of waxing on certain physiological processes of cucumbers under different storage conditions. Food Res. 7:38-47.

Morris, L.L. 1982. Chilling injury of horticultural crops: an overview. HortScience 17:161-164.

Ryan, A.L. and W.J. Lipton. 1979. Handling, transportation and storage of fruits and vegetables. AVI, Westport, Corm. p. 28-29.

Saltveit, M. E., Jr., and R.M. Cabrera. 1987. Tomato fruit temperature before chilling influences ripening after chilling. HortScience 22:452454.

Saltveit, M. E., Jr., and R.F. McFeeters. 1980. Polygalacturonase activity and ethylene synthesis during cucumber fruit development and maturation. Plant Physiol. 66:1019-1023.

Saltveit, M. E., Jr., and L.L. Morris. 1989. Overview on chilling injury of horticultural crops, p. 1-14. In: C.Y. Wang (cd.). Chilling injury of horticultural crops. CRC Press, Boca Raton, Fla.

Wang, C.Y. 1982. Physiological and biochemical responses of plants to chilling stress. HortScience 17:173-186.

Wang, C.Y. and R.E. Anderson. 1982. Progress on controlled atmosphere storage and intermittent warming of peaches and nectarines. Proc. 34th Natl. CA Res. Conf., Oregon State Univ. Corvallis. Timber Press. Beaverton, Ore. p. 221-228.

Wang, C.Y. and D.O. Adams. 1981. Effects of chilling on ethylene production in cucumbers. Plant Physiol. 67:563.

Wang, C.Y. and D.O. Adams. 1980. Ethylene production by chilled cucumbers (Cucumis sativa). Plant Physiol. 66:841-843.

Wang, C.Y. and J.E. Baker. 1979. Effects of two free radical scavengers and intermittent warming on chilling injury and polar lipid composition of cucumber and sweet pepper fruits. Plant\& Cell Physiol. 20:243-251.

Wheaton, T.A. and L.L. Morris. 1967. Modification of chilling sensitivity by temperature conditioning. Proc. Amer. Soc. Hort. Sci. 91:529-533.

Yang, S.F. 1980. Regulation of ethylene biosynthesis. HortScience 15:238-243. 